\title{
Hairy Cell Count
}

National Cancer Institute

\section{Source}

National Cancer Institute. Hairy Cell Count. NCI Thesaurus. Code C74604.

The determination of the number of hairy cells present in a sample. 